
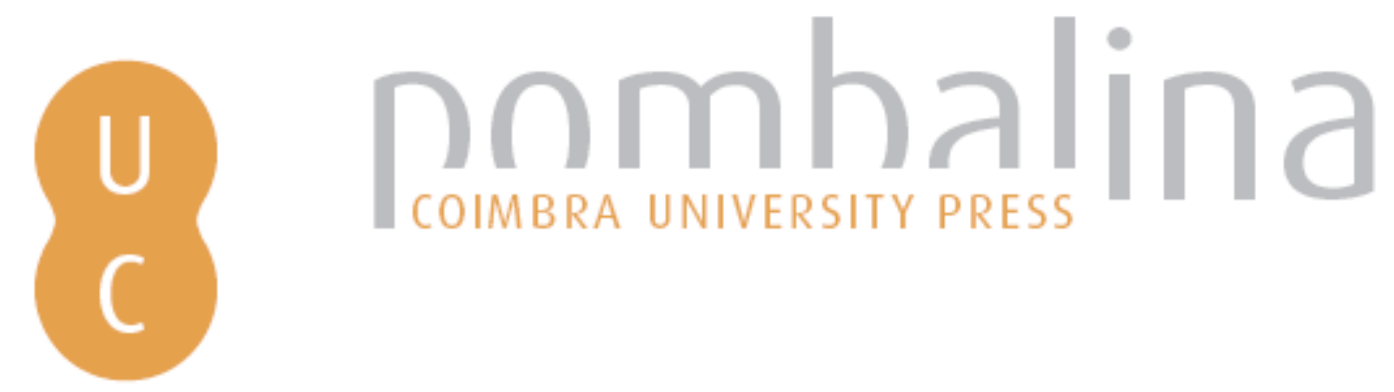

\title{
Past fire practices and new steps towards an effective fire management approach in the Brazilian savannas
}

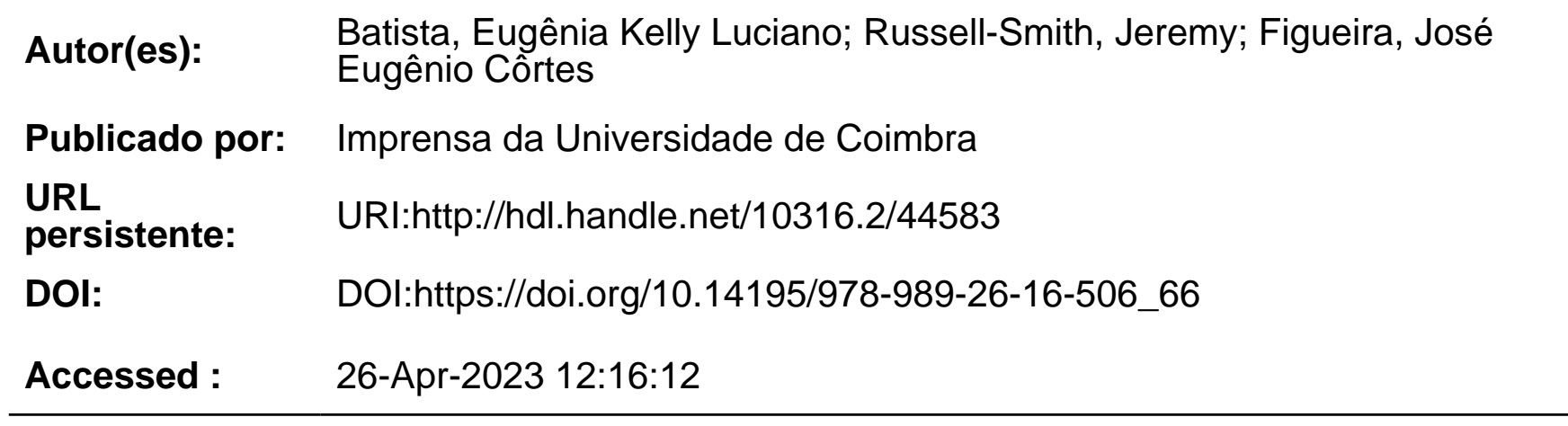

A navegação consulta e descarregamento dos títulos inseridos nas Bibliotecas Digitais UC Digitalis, UC Pombalina e UC Impactum, pressupõem a aceitação plena e sem reservas dos Termos e Condições de Uso destas Bibliotecas Digitais, disponíveis em https://digitalis.uc.pt/pt-pt/termos.

Conforme exposto nos referidos Termos e Condições de Uso, o descarregamento de títulos de acesso restrito requer uma licença válida de autorização devendo o utilizador aceder ao(s) documento(s) a partir de um endereço de IP da instituição detentora da supramencionada licença.

Ao utilizador é apenas permitido o descarregamento para uso pessoal, pelo que o emprego do(s) título(s) descarregado(s) para outro fim, designadamente comercial, carece de autorização do respetivo autor ou editor da obra.

Na medida em que todas as obras da UC Digitalis se encontram protegidas pelo Código do Direito de Autor e Direitos Conexos e demais legislação aplicável, toda a cópia, parcial ou total, deste documento, nos casos em que é legalmente admitida, deverá conter ou fazer-se acompanhar por este aviso.

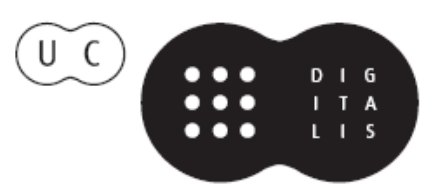




\section{ADVANCES IN}

\section{FOREST FIRE RESEARCH}

\section{8}

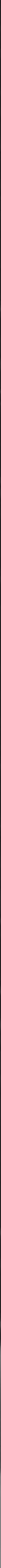




\title{
Past fire practices and new steps towards an effective fire management approach in the Brazilian savannas
}

\author{
Eugênia Kelly Luciano Batista ${ }^{1 *}$; Jeremy Russell-Smith ${ }^{2}$; José Eugênio Côrtes Figueira ${ }^{1}$ \\ ${ }^{1}$ Department of General Biology, Federal University of Minas Gerais. 6627 Presidente Antônio \\ Carlos Ave, Belo Horizonte, MG, Brazil, \{biogenia.k@gmail.com*\} \\ ${ }^{2}$ Darwin Centre for Bushfire Research, Charles Darwin University. Ellengowan Drive, \\ Casuarina, Darwin, Australia \{Jeremy.Russell-Smith@cdu.edu.au\}
}

\begin{abstract}
Every year, widespread and severe fires cause loss of biodiversity and changes in the structure and functioning of savanna ecosystems. Currently, the Brazilian savanna (Cerrado) is threatened by the absence of a consistent fire policy. Most protected areas in Brazil still apply total fire suppression policies, instead of a more integrated fire management approach. Faced with the challenge of reconciling biodiversity conservation goals with rural livelihoods, scientists, policymakers and managers around the world have discussed potential solutions for managing fire in protected areas aimed at the sustainability of these ecosystems. Based on international experiences, an Integrated Fire Management Pilot Program was recently implemented in three Brazilian protected areas, while an adaptive and integrated approach has progressively raised the interest of other park managers. Initially, goals and actions have focused on protecting fire-sensitive vegetation and reducing the extent of areas burned, particularly at the end of the dry season. To achieve this, managers are making use of patch mosaic burning techniques to create mosaics of burnt and unburnt areas that purportedly decrease the probability of large wildfires and hence increase fire interval in fire-sensitive areas. However, despite advances in fire management policies in Brazilian savannas, an adaptive approach requires a continuous assessment of managed ecosystems, through which managers and ecologists can obtain knowledge about the responses of species and natural communities. Without a clear definition of appropriate ecological parameters, it is not possible to be sure if management actions or fire regime thresholds are actually delivering benefits for sustainable long-term biodiversity conservation. In this study, we use the example of the Canastra National Park (CNP) - Southeastern Brazil, to illustrate how widely employed suppression policies can result in inappropriate fire regimes and how these results have encouraged current changes in fire management perspectives.
\end{abstract}

Keywords: Fire regimes, Adaptive fire management, Suppression policies, Ecological monitoring, Cerrado.

\section{Suppression policies and recent changes in fire management}

Fire suppression policies have proved to be unsuitable for fire-prone environments but are still predominant in protected areas of Brazilian savannas. On the one hand, suppression policies are often associated with fire use criminalization and generally result in increased social conflicts (Batista et al. 2018). Without a dialogue with people who use fire as a management tool, it is expected that large and severe fires will occur more than would be both ecologically and socially tolerable. On the other hand, without fires, large amounts of biomass may accumulate rapidly after rains, being available for burning late in the dry season. These fires are potentially destructive because they are typically severe, less patchy (smaller and fewer unburned patches) and often grow to a large size (Oliveira et al. 2015). The homogenization of fire histories and landscape structure through large areas makes the recovery slower, especially for species with low dispersal capacity which depend on the migration of individuals from nearby areas across unsuitable habitat (Mendonça et al. 2015; Bowman and Legge 2016).

Advances in Forest Fire Research 2018 - Page 598 
It is also important to consider that slow-moving animals, those unable to fly, or with small home ranges can be easily burned during fast and hot grassland fires (Redford 1994; Koproski et al. 2006; Yates et al. 2008; Massochini Frizzo et al. 2011). Even those species that live in burrows or rock gaps can decline in abundance sometime after fire, emphasizing the relevance of indirect fire effects (especially large-scale and low-patchiness fires) on the sustainability of these species (Lawes et al. 2015). In particular, wildfires occurring at the end of dry season typically are of high intensity and with higher speed of fire fronts, which may intensify the mortality of plants and animals. These fires are of great concern in Brazilian savannas, because at the same period, animals are producing young and plants are investing in reproductive structures (Falleiro 2011). Young individuals are less able to escape or protect themselves from the flames. In plants, severe fires cause an immediate reduction in sexual reproductive success by causing abortion of flowers and fruits, interrupting the reproductive cycle and forcing vegetative resprouting (Hoffmann 1998).

From another perspective, too frequent, severe and large fires certainly result in significant economic damages. Large resource amounts are expended on fire fighting in Brazil annually. An average of $\mathrm{R} \$ 15$ million from the annual federal budget is destined to prevention and control of fires. Just in Minas Gerais, a state that encompasses many protected areas of Brazilian Cerrado, more than $\mathrm{R} \$ 20$ million is expended on fire prevention and control, mostly with airplanes and ground-based activities. Neither costs nor fire damages have reduced significantly throughout the time, which indicates that our strategies, in addition to be very expensive, are probably ineffective.

The apparent resistance in changing perspectives and actions seems to be related to a cultural heritage which considers that fire always has a negative impact on biodiversity (Bilbao et al. 2010; Durigan and Ratter 2016). Some ecologists and managers have argued that it is not possible to manage fire without scientific knowledge that could help to define ideal fire regimes for each ecosystem and support management decisions with a focus on biodiversity conservation. Meanwhile, the absence of a consistent fire management policy has resulted in inappropriate fire regimes and loss of biodiversity (Durigan and Ratter 2016).

When faced with similar challenges, Australian and South African managers concluded that fire was a natural component of savanna ecosystems that should not be excluded but properly managed to ensure the balance and sustainability of these habitats (Russell-Smith et al. 1998; Edwards et al. 2013; Van Wilgen et al. 2014). So, after years of an adaptive approach, managers and ecologists have learned by doing and currently they are able to refine their goals and actions focused on biodiversity conservation.

In Brazil, encouraged by successful international experiences and supported by federal legislation, Brazilian Environmental Agencies have implemented alternative and innovative fire management practices in some National Parks (Schmidt et al. 2018). Since 2014-2015, protected areas have been burned intentionally early in the dry season aiming to increasing the fire interval in fire-sensitive areas, producing heterogeneity and preventing high-intensity fires from reaching large sizes (Fig.1). These changes, although incipient and unrepresentative, have instigated discussions and stimulated the development of research that attempts to understand the role of fire in savanna ecosystems. 
(a)

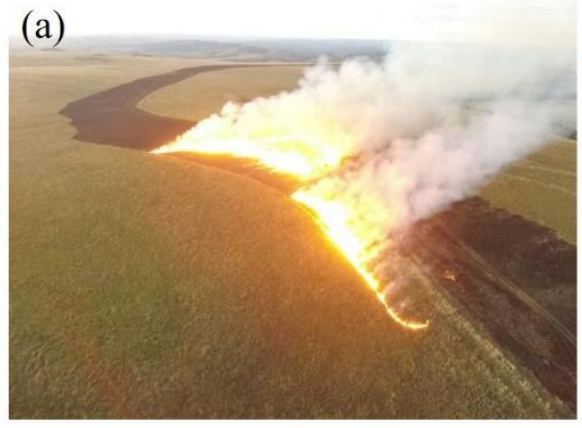

(b)
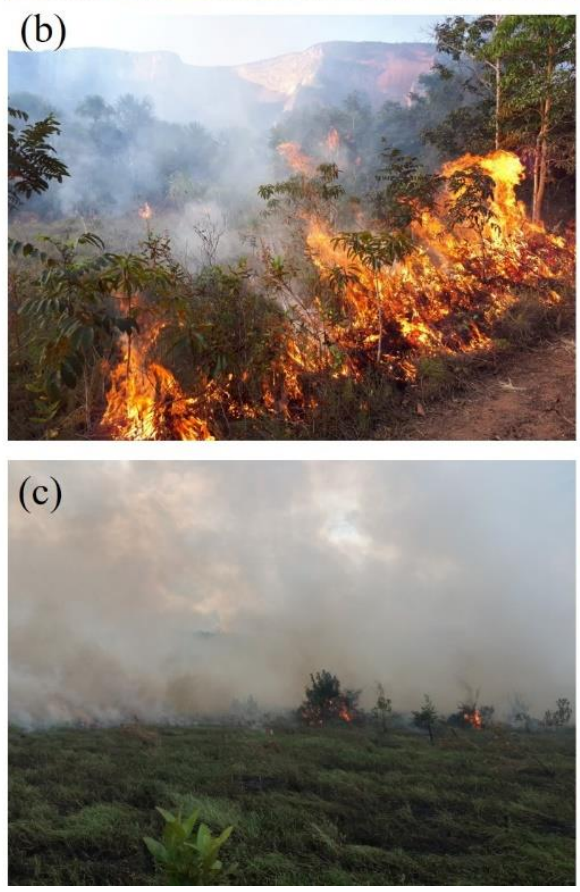
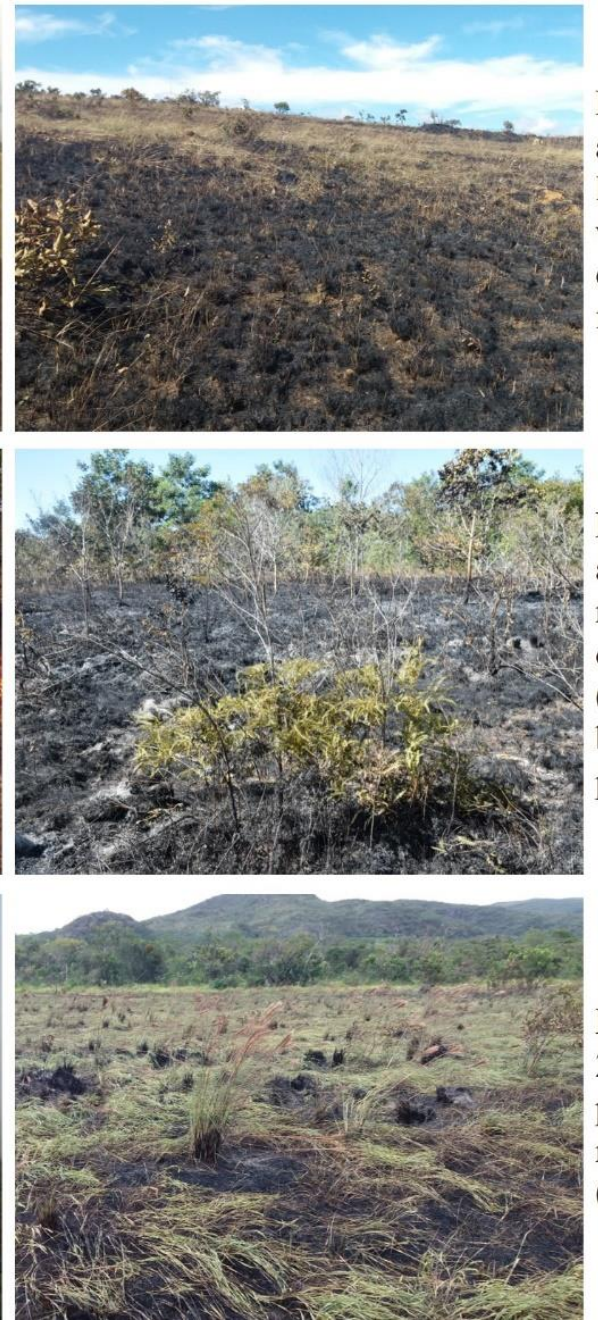

Prescribed burning in July 2016 at the CNP. Main goal: prevent large fires by increasing the width of firebreaks and establishing discontinuities in the fuel layer.

Prescribed burning in June 2018 at the CGNP. Main goal: create a mosaic of vegetation with different post-fire ages (pyrodiversity) focused on biodiversity conservation and preventing large fires.

Prescribed burning in March 2018 at the CiNP. Main goal: prevent severe fires from reaching fire-sensitive vegetation (riparian forest).

Figure 1 - Fire management in Brazilian savannas. To the left, prescribed burning. To the right, burned areas just after the fire. Note that planned fires are typically mild and patchy. At Canastra National Park (CNP) (a), the main concern has been to reduce the risks of large fires. At Chapada dos Guimarães National Park (CGNP) (b), managers have applied prescribed burnings to create a mosaic of patches in different post-fire ages. The idea is to introduce pyrodiversity expecting that the ecosystem will be able to sustain greater biodiversity. At Serra do Cipó National Park (CiNP) (c), first prescribed burnings are focused on the protection of fire-sensitive vegetation (forests).

In contrast, protected areas managed by the Brazilian States continue to support total suppression policies. Due to more restrictive legislation, the use of fire to manage landscapes and biodiversity is actually prohibited in most of these sites. As a result, large and severe fires burn extensive areas every year, causing serious damages to biodiversity and making it necessary to allocate much of the resources for firefighting rather than prevention (Fig.2). Advances in fire management policies in State protected areas would only be possible through adjustments in current legislation. 


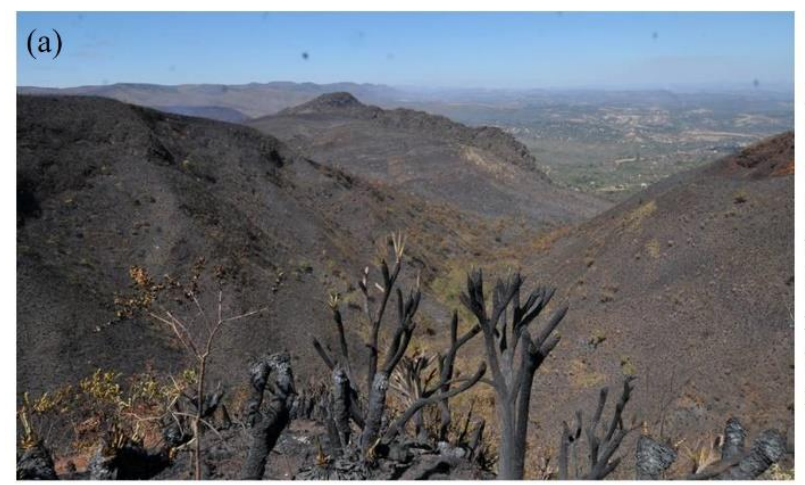

Large fires occur frequently in the Serra do Rola Moça State Park, Southeastern Brazil. In 2011, about $50 \%$ of the Park were burned, including fire-sensitive vegetation around springs and riparian forest. In 2015, large and severe fires burned again around 55\% of the Park. Repeated fires can be seriously damaging, especially for fire-sensitive vegetation. Since inappropriate fire regimes may reduce the woody cover around springs and rivers, it is possible that the capacity of these habitats to collect and store water is also being negatively affected.

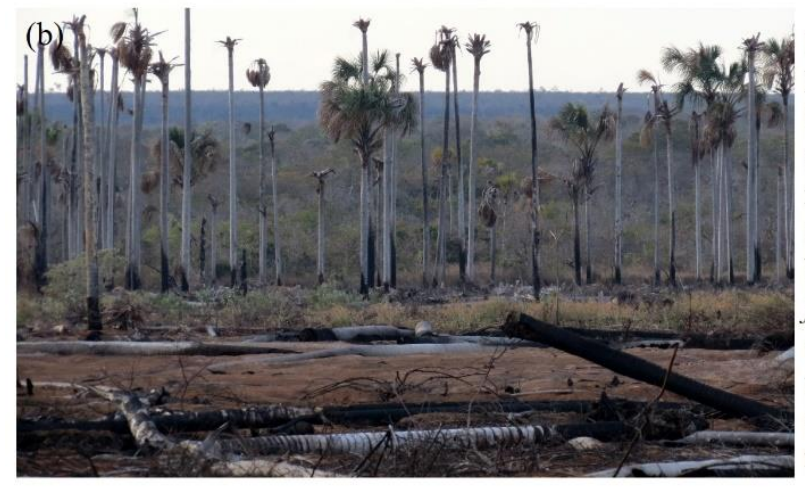

In 2017, a fire lit by a farmer in a swampy area along the Peruaçu River burned out of control and moved into the Veredas do Peruaçu State Park, Southeastern Brazil. From there, it proceeded to burn amidst grass, bushes, and palm trees (Mauritia flexuosa) for eight months. This fire smoldered underground in dried out, carbon-rich soil, spread slowly through soil and roots without any visible flames, but it was able to move up the hollow trunks of the Mauritia flexuosa and jump to the palm tree canopy. In that region, water consumption has been greater than recharge, reducing the flow of the Peruaçu River. As a result, the level of groundwater has reduced, drying up the palm swamps and making them more susceptible to new fires.

Figure 2 - Wildfires in Brazilian savannas. Large and severe fires occurring in two State Parks ((a)Serra do Rola Moça State Park and (b) Veredas do Peruaçu State Park) as a result of fire suppression policies still predominant in Brazil.

\section{Future challenges for fire management}

Firstly, fire management issues facing fire-prone ecosystems are symptomatic of ongoing conflicts between official fire exclusion policies in conservation reserves, and the livelihood aspirations and imperatives of embedded and surrounding local communities. We contend that an adaptive, inclusive approach between conservation agency authorities and local communities needs to be adopted for defining, and then collaboratively implementing, appropriate fire regimes which deliver benefits both for sustainable long-term biodiversity conservation and livelihood outcomes. Reconciling these apparently contradictory interests is the best possible solution to reduce ignitions and large, severe wildfires in protected areas.

Secondly, adaptive management provides a useful framework for integrating science and management and enables managers to work with uncertainty, incomplete knowledge and unreplicated studies. In adaptive forms of management, decisions are made as part of an ongoing process of review and evaluation of results. It involves a clear delineation of objectives, targets or thresholds of potential concern (TPC), the implementation of management actions, and the monitoring of outcomes in terms of agreed targets or thresholds (Van Wilgen et al. 2011).

If thresholds are exceeded, interventions must be done to drive the system back to within thresholds, or, alternatively, thresholds can be re-calibrated.

However, incorporating ecological thresholds into management is not a trivial task, especially in Brazilian savannas, whose landscapes are typically heterogeneous. Thus, the first issue that comes with ecological thresholds is: what is the conservation value of a given ecosystem or vegetation structure and what is the fire regime that will maintain these values? But even with clear fire regime thresholds, we can only be sure that they are actually delivering benefits for sustainable long-term 
biodiversity conservation if we monitor key ecological predictors. So, a second issue for ecologists and land managers is: what would be these predictors and how might they be assessed?

Finally, we will use the example of the Canastra National Park for making managers familiar with ecological thresholds for fire regimes and how to incorporate them into decision-making processes.

\section{Fire and management in the Canastra National Park}

The Canastra National Park was created in April 1972 and currently comprises an area of 197787 ha. In grassland areas it is mostly a short-memory system, with rapid fuel accumulation and curing of grasses and litter at the beginning of the dry season associated with low canopy cover. The uplands are characterized by an extensive matrix of grasses interspersed by small disconnected forest patches. Together, these features make the system highly vulnerable to the occurrence of large fires, which in turn creates uniformity in fire history and landscape structure, increasing the chances of subsequent large fire events. Generally, fires are initiated by farmers near, or in properties embedded within, the CNP. These fires invade the uplands and quickly become out of control (Fig.3).

$09 / 14 / 2006$

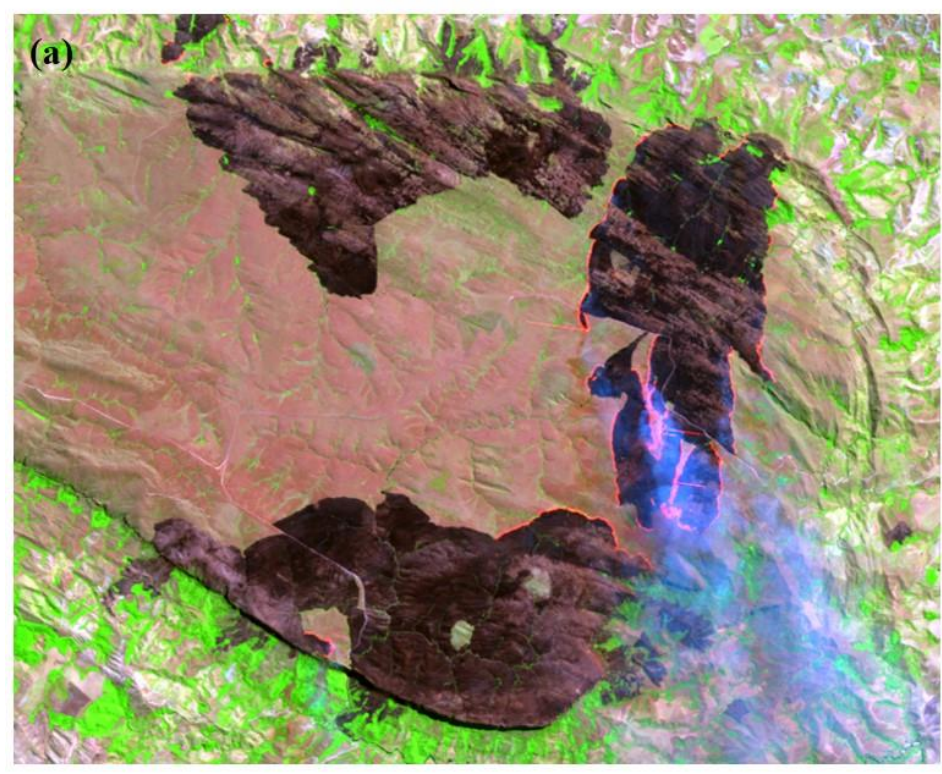

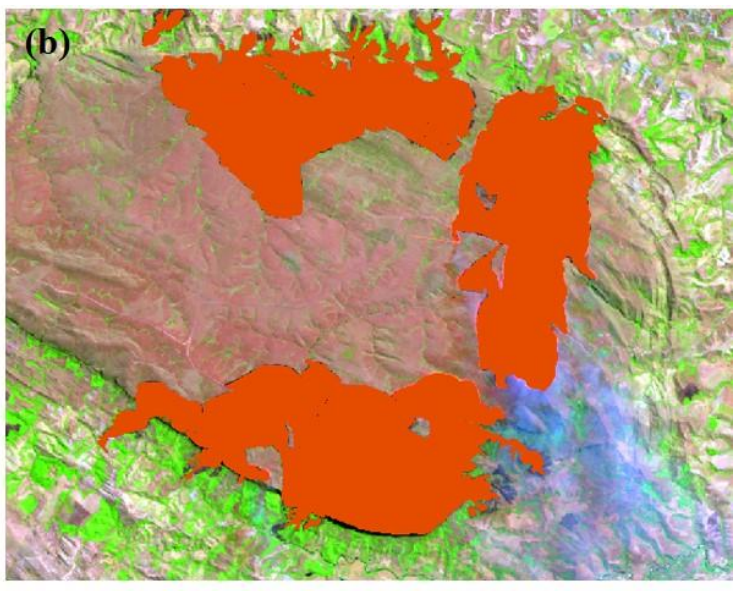

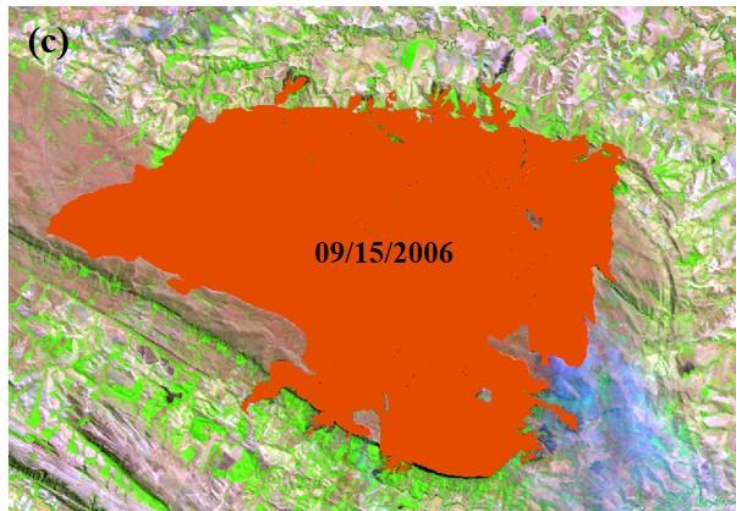

Figure 3 - Wildfires in the Canastra National Park. Fires usually are initiated by farmers near, or in properties embedded within, the CNP. These fires rapidly spread through the extensive and homogeneous grasslands and become out of control. (a) Landsat TM image (September 14th, 2006) showing different active fires invading the uplands of the Park. (b) Fire scars at the same day. (c) Fire scars extracted from subsequent images showing how quickly the fire spreads in this landscape. The date of scars was estimated through daily hotspots downloaded from the INPE website (http://www.inpe.br/queimadas/bdqueimadas).

Pastoral management undertaken by landowners is performed on patches with predominant biennial rotation, allowing the fire to occur annually and making the system entirely dependent on the fuel accumulation rates (bottom-up control). Concurrently, social conflicts intrinsic to the historical background and fire suppression policies increase the risk of unplanned fires late in the dry season. Given the high frequency of large and severe fires, especially in fire-sensitive habitats, the current fire 
regime and associated management arrangements are unlikely to deliver required sustainable biodiversity conservation management outcomes.

In an attempt to make the fire regime compatible with conservation goals, current managers have introduced alternative strategies and actions into fire management. Since 2017, prescribed burnings are being applied in grasslands to produce firebreaks perpendicular to each other. The main objective is to reduce the extent of wildfires and facilitate the fire control by creating discontinuities in the fuel layer. According to the parks' recently published Integrated Fire Management Plan, uplands will be divided into sectors that will be burnt alternately every two years. The Plan also recommends the creation of firebreaks in areas bordering the Park and around fire-sensitive vegetation, such as forests patches.

To implement thresholds appropriately, we propose to define a set of Fire Management Units (FMU) grouping physiognomies with similar fire requirements according to accumulated knowledge on the responses of species, populations and communities to fire regimes. The above delineation reveals two major FMUs: (1) Forests (fire-sensitive ecosystems) and (2) Grasslands/wooded savannas (fire-dependent ecosystems).

Forest patches in the CNP are generally small in size, which make them particularly vulnerable to fire impacts and ultimately extinction. The thin bark of forest species does not provide thermal protection to the vascular system and severe fires are usually able to kill the trees (Hoffmann and Solbrig 2003). After burning and death of trees, forest edges suffer biomass collapse and microclimate changes increasing openness making them susceptible to subsequent fire incursions. In addition, repeated topkill of saplings, sprouts and young trees prevents recruitment into adult size classes. In the course of this study, trees killed by fire were observed on the edges of forest patches of uplands, where very small patches were entirely burnt. Management actions in this FMU should focus on protecting and improving the quality of these habitats, minimizing the risk of severe fires, increasing biodiversity and controlling the edge-effects. We propose that no deliberate burning should be performed inside these units. Any late dry season fire should be extinguished. To protect the forests from fire incursions, some fuel control should be performed next to the patch borders and the maintenance of long-unburnt areas around these forest patches should be encouraged through reducing the frequency of fires. We suggest that monitoring should focus on forest -dependent taxa and specialists, sedentary species or distance-limited dispersers, and late successional species (rare and shade-tolerant). The presence of these species in viable populations would suggest that despite being a fragmented landscape, forest patches are able to support more demanding species (Broeck et al. 2017). Parameters related to the size of forest patches, their distribution through the landscape and edge effects could also be used to assess improvements in quality of these habitats after fire management (Didham and Lawton 1999; Hill and Curran 2003; Berry et al. 2015).

Grasslands and wooded savannas from the CNP are affected by large, severe and frequent wildfires. Homogenization of fire histories through large areas can delay or prevent the recovery process, especially by species with low dispersal capacity. Large fires can be especially deleterious to small, isolated populations of small mammals, slow-moving animals or those unable to fly or with small home ranges causing direct mortality, increased exposure to predators, and destruction of neighboring potential source areas. Basically, management actions in this FMU should focus on reducing the extent of wildfires (particularly at the end of the dry season), maintenance of intact unburnt vegetation and introduction of fire heterogeneity. We suggest reducing the fire frequency close to forest patches, by establishing long-unburnt areas (>2-9 years) to minimize the edge-effects on these habitats. Deliberate burning should be conducted in the grasslands before the late dry season months with the aim of increasing spatial heterogeneity, such that patches of unburnt vegetation are compartmentalized between recently burned areas and a system of strategically placed firebreaks. It would be advisable to monitor populations of small mammals, ground-dwelling birds and reptiles. These species are particularly vulnerable to increased predation after large and severe fires (Bowman and Legge 2016). 
In plants, obligate seeders and monocarpic species should be monitored for being more vulnerable to frequent fires (Noble and Slatyer 1980; Whelan 1995; Burrows et al. 2008; Figueira et al. 2016).

\section{Conclusions}

Faced with the need for a consistent fire management policy, Brazilian managers and ecologists have discussed potential solutions especially concerned with the sustainability of savanna ecosystems. The key challenge is getting park authorities and local communities to work together to devise effective fire management processes and programs. Successful integrated fire management would result in reducing the number of unplanned fires and the costs involved in firefighting. It is also important to clearly define management objectives and appropriate fire regime thresholds for each particular ecosystem. To ensure that management actions are delivering benefits for sustainable long-term biodiversity conservation, it is crucial that continuous assessment of managed ecosystems is undertaken through which managers and ecologists can actively obtain knowledge about species and natural communities ("learning by doing").

\section{References}

Batista EKL, Russell-Smith J, França H, Figueira JEC (2018) An evaluation of contemporary savanna fire regimes in the Canastra National Park, Brazil: Outcomes of fire suppression policies. Journal of Environmental Management 205, 40-49. doi:10.1016/j.jenvman.2017.09.053.

Berry LE, Lindenmayer DB, Driscoll D a. (2015) Large unburnt areas, not small unburnt patches, are needed to conserve avian diversity in fire-prone landscapes. Journal of Applied Ecology 52, 486495. doi:10.1111/1365-2664.12387.

Bilbao B a., Leal A V., Méndez CL (2010) Indigenous use of fire and forest loss in Canaima National Park, Venezuela. Assessment of and tools for alternative strategies of fire management in Pemón Indigenous Lands. Human Ecology 38, 663-673. doi:10.1007/s 10745-010-9344-0.

Bowman DMJS, Legge S (2016) Pyrodiversity - why managing fire in food webs is relevant to restoration ecology. Restoration Ecology 24, 848-853. doi:10.1111/rec.12401.

Broeck A Vanden, Maes D, Kelager A, Wynhoff I, Wallisdevries MF, Nash DR, Oostermeijer JGB, Dyck H Van, Mergeay J (2017) Gene flow and effective population sizes of the butterfly Maculinea alcon in a highly fragmented, anthropogenic landscape. Biological Conservation 209, 89-97. doi:10.1016/j.biocon.2017.02.001.

Burrows ND, Wardell-Johnson G, Ward B (2008) Post-fire juvenile period of plants in south-west Australia forests and implications for fire management. Journal of the Royal Society of Western Australia 91, 163-174.

Didham RK, Lawton JH (1999) Edge Structure Determines the Magnitude of Changes in Microclimate and Vegetation Structure in Tropical Forest Fragments. Biotropica 31, 17-30. doi:10.1111/j.17447429.1999.tb00113.x.

Durigan G, Ratter JA (2016) The need for a consistent fire policy for Cerrado conservation. Journal of Applied Ecology 53, 11-15. doi:10.1111/1365-2664.12559.

Edwards AC, Maier SW, Hutley LB, Williams RJ, Russell-smith J (2013) Spectral analysis of fire severity in north Australian tropical savannas. Remote Sensing of Environment 136, 56-65. doi:10.1016/j.rse.2013.04.013.

Falleiro RDM (2011) Resgate do manejo tradicional do Cerrado com fogo para proteção das Terras Indígenas do oeste do Mato Grosso: um estudo de caso. Revista Biodiversidade Brasileira 1, 8696. 
Figueira JEC, Ribeiro KT, Ribeiro MC, Jacobi CM, França H, Neves ACO, Conceição AA, Mourão FA, Souza JM, Knegt CA de M (2016) Fire in rupestrian grasslands: plant response and management. 'Ecol. Conserv. Mt. grasslands Brazil'. (Ed GW Fernandes) pp. 1-34. (Springer International Publishing Switzerland: Belo Horizonte)

Hill JL, Curran PJ (2003) Area, shape and isolation of tropical forest fragments: effects on tree species diversity and implications for conservation. Journal of Biogeography 30, 1391-1403. doi:10.1046/j.1365-2699.2003.00930.x.

Hoffmann WA (1998) Post-burn reproduction of woody plants in a neotropical savanna: The relative importance of sexual and vegetative reproduction. Journal of Applied Ecology 35, 422-433. doi:10.1046/j.1365-2664.1998.00321.x.

Hoffmann WA, Solbrig OT (2003) The role of topkill in the differential response of savanna woody species to fire. Forest Ecology and Management 180, 273-286. doi:10.1016/S03781127(02)00566-2.

Koproski L, Mangini PR, Pachaly JR, Batista AC, Soares RV (2006) Impactos do fogo sobre serpentes (Squamata) no Parque Nacional de Ilha Grande (PR/MS), Brasil. Arquivos de Ciências Veterinárias e Zoologia da Unipar 9, 129-133. doi:10.25110/arqvet.v9i2.2006.355.

Lawes MJ, Murphy BP, Fisher A, Woinarski JCZ, Edwards AC, Russell-Smith J (2015) Small mammals decline with increasing fire extent in northern Australia: Evidence from long-Term monitoring in Kakadu National Park. International Journal of Wildland Fire 24, 712-722. doi:10.1071/WF14163.

Massochini Frizzo TL, Bonizário C, Borges MP, Vasconcelos HL (2011) Revisão dos efeitos do fogo sobre a fauna de formações savânicas do Brasil. Oecologia Australis 15, 365-379. doi:10.4257/oeco.2011.1502.13.

Mendonça AF, Armond T, Camargo ACL, Camargo NF, Ribeiro JF, Zangrandi PL, Vieira EM (2015) Effects of an extensive fire on arboreal small mammal populations in a neotropical savanna woodland. Journal of Mammalogy 96, 368-379. doi:10.1093/jmammal/gyv038.

Noble IR, Slatyer RO (1980) The use of vital attributes to predict successional changes in plant communities subject to recurrent disturbances. Vegetatio 43, 5-21. doi:10.1007/BF00121013.

Oliveira SLJ, Campagnolo ML, Price OF, Edwards AC, Russell-Smith J, Pereira JMC (2015) Ecological implications of fine-scale fire patchiness and severity in tropical savannas of Northern Australia. Fire Ecology 11, 10-31. doi:10.4996/fireecology.1101010.

Redford KH (1994) The edentates of the Cerrado. Edentata 1, 4-10.

Russell-Smith J, Ryan PG, Klessa D, Waight G, Harwood R (1998) Fire regimes, fire-sensitive vegetation and fire management of the sandstone Arnhem Plateau, monsoonal northern Australia. Journal of Applied Ecology 35, 829-846.

Schmidt IB, Moura LC, Ferreira MC, Eloy L, Sampaio AB, Dias PA, Berlinck CN (2018) Fire management in the Brazilian Savanna: first steps and the way forward. Journal of Applied Ecology. doi:10.1111/1365-2664.13118.

Whelan J. R (1995) 'The Ecology of Fire.' (Cambridge University Press: Cambridge, UK)

Van Wilgen BW, Govender N, Forsyth GG, Kraaij T (2011) Towards adaptive fire management for biodiversity conservation: Experience in South African National Parks. Koedoe 53, 1-9. doi:10.4102/koedoe.v53i2.982.

Van Wilgen BW, Govender N, Smit IPJ, MacFadyen S (2014) The ongoing development of a pragmatic and adaptive fire management policy in a large African savanna protected area. Journal of Environmental Management 132, 358-368. doi:10.1016/j.jenvman.2013.11.003. 
Advances in Forest Fire Research 2018 - D. X. Viegas (Ed.)

Chapter 3 - Fire Management

Yates CP, Edwards AC, Russell-Smith J (2008) Big fires and their ecological impacts in Australian savannas: Size and frequency matters. International Journal of Wildland Fire 17, 768-781. 